\title{
Sistem Pendukung Keputusan Untuk Menentukan Penerima Bantuan RSRTLH Menggunakan metode Weight Sum Model (WSM) pada Desa Tanjung Garbus 1 Kecamatan Lubuk Pakam
}

\author{
Milfa Yetri \\ Program Studi Sistem Informasi, STMIK Triguna Dharma
}

\begin{abstract}
Article Info
ABSTRACT

Article history:

Received Jun $12^{\text {th }}, 2020$

Revised Aug 20", 2020

Accepted Aug 26 $6^{\text {th }}, 2020$

Keyword:

Sistem Pendukung Keputusan, RSRTLH, Weight Sum Model.

RSRTLH (Rehabilitasi Sosial Rumah Tidak Layak Huni) merupakan salah satu program bantuan yang diberikan oleh Departemen Sosial Republik Indonesia yang setiap tahunnya di adakan yang bertujuan untuk membantu mengatasi kemiskinan di Indonesia dengan cara merenovasi rumah-rumah yang tidak layak huni. Dalam hal ini Departemen Sosial Republik Indonesia telah menerapkan beberapa kriteria untuk menentukan penerima bantuan RSRTLH.

Oleh karena itu, diperlukan suatu proses untuk menentukan RSRTLH (Rehabilitasi Sosial Rumah Tidak Layak Huni) dengan penerapan sistem yang disebut sistem pendukung keputusan. Sistem Pendukung Keputusan merupakan sistem yang membantu pengambilan keputusan untuk melengkapi informasi dari data yang telah diolah secara relevankarena juga menggunakan suatu proses perhitungan dengan menggunakan metode WSM (weight sum model). WSM (weight sum model) merupakan metode sederhana dan paling sering digunakan. Metode ini juga metode yang paling mudah untuk diaplikasikan, karena mempunyai algoritma yang tidak terlalu rumit.

Hasil dari penelitian ini berupa aplikasi yang dapat membantu pegawai agar dapat memberikan bantuan RSRTLH secara tepat dan akurat berdasarkan kriteria-kriteria yang telah ditetapkan.
\end{abstract}

Copyright $\odot 2020$ STMIK Triguna Dharma. All rights reserved.

\footnotetext{
Corresponding Author: *First Author

Nama : Milfa Yetri

Kantor : STMIK Triguna Dharma

Program Studi : Sistem Informasi

E-Mail : Airputih.girl@gmail.com
} 


\section{PENDAHULUAN}

RSRTLH (Rehabilitasi Sosial Rumah Tidak Layak Huni) merupakan salah satu program bantuan yang diberikan oleh Departemen Sosial Republik Indonesia yang setiap tahunnya di adakan yang bertujuan untuk membantu mengatasi kemiskinan di Indonesia dengan cara merenovasi rumah-rumah yang tidak layak huni. Dalam hal ini Departemen Sosial Republik Indonesia telah menerapkan beberapa kriteria untuk menentukan penerima bantuan RSRTLH.

Program RSRTLH yang di berikan oleh Departemen Sosia 1Republik Indonesia ini adalah program bantuan untuk kesejahteraan warga-warga desa yang kondisi rumahnya jauh dari kata layak huni, dengan bertujuan untuk mengatasi sebagian masalah kemiskinan, tersedianya rumah layak huni dan adanya kenyamanan bertempat tinggal.

Berdasarkan uraian di atas, maka skripsi ini ditulis dengan judul "Sistem Pendukung Keputusan Untuk Menentukan Penerima Bantuan RSRTLH menggunakan metode Weight Sum Model (WSM) pada desa tanjung Garbus 1 Kecamatan Lubuk Pakam.

\section{METODELOGI PENELITIAN}

\subsection{Sistem Pendukung Keputusan}

Menurut Alter (dalam Kusrini,2007:15) Sistem pendukung keputusan merupakan sistem informasi interaktif yang menyediakan informasi, pemodelan,dan pemanipulasian data.Sistem itu digunakan untuk membantu pengambilan keputusan dalam situasi yang semistruktur dan situasi yang tidak terstruktur, dimana tak seorang pun tau secara pasti bagaimana keputusan seharusnya dibuat.

Sistem pendukung keputusan biasanya dibangun untuk mendukung solusi atas suatu masalah atau untuk mengevaluasi suatu peluang.Sistem pendukung keputusan yang seperti itu disebut aplikasi sistem pendukung keputusan.Aplikasi sistem pendukung keputusan menggunakan CBIS (Computer Based information System) yang fleksibel, interaktif, dan dapat diadaptasi, yang di kembangkan untuk mendukung solusi atas masalah manajemen spesifik yang tidak terstruktur

\subsection{RSRTLH (Rehabilitasi Rumah Tidak Layak Huni)}

RSRTLH (Rehabilitasi Sosial Rumah Tidak Layak Huni) merupakan salah satu program bantuan yang diberikan oleh Departemen Sosial Republik Indonesia yang setiap tahunnya di adakan yang bertujuan untuk membantu mengatasi kemiskinan di Indonesia dengan cara merenovasi rumah-rumah yang tidak layak huni. Dalam hal ini Departemen Sosial Republik Indonesia telah menerapkan beberapa kriteria untuk menentukan penerima bantuan RSRTLH.

\subsection{Weight Sum Model (WSM)}

Weigth Sum Model (WSM) merupakan metode yang sangat umum, dan banyak diterapkan untuk membantu pengambil keputusan dalam mengambil suatu keputusan. Metode WSM merupakan salah satu metode yang paling sederhana dan mudah dipahami penerapannya di karenakan dalam konsep metode ini hanya melakukan perkalian di antara Bobot Kriteria $\left(\mathrm{W}_{\mathrm{j}}\right)$ dan nilai Alternatif $\left(\mathrm{W}_{\mathrm{ij}}\right)$. Metode ini merupakan bagian dalam metode MCDM (Multi-CriteriaDecision Making) dalam mengevaluasi nilai pada setiap alternatifnya.

$$
\mathrm{Ai}^{\mathrm{WSM}-\mathrm{score}}=\sum_{j=i}^{n} w_{j}{ }^{x i j}
$$

Dimana :

$\mathrm{n} \quad=$.jumlah kriteria

$\mathrm{w}_{\mathrm{j}}=$ bobot dari setiap kriteria

$\mathrm{x}_{\mathrm{ij}}=$ nilai matrik $\mathrm{x}$

\section{HASIL DAN PEMBAHASAN}

Penerapan metode Weight Sum Model ini merupakan metode sangat sederhana dengan hanya beberapa langkah untuk dapat memberikan hasil penentuan penerima bantuan RSRTLH pada desa Tanjung Garbus 1 Kecamatan Lubuk Pakam. Keputusan yang dihasilkan dengan penerapan WSM bukan keputusan mutlak 
yang di gunakan perangkat desa untuk memutuskan masyarakat penerima bantuan RSRTLH tersebut. Prosesproses yang dilakukan pada Weight Sum Model (WSM) memerlukan kriteria-kriteria yang mempengaruhi penerima (alternatif) dalam perhitungannya.

Tabel.1 Kriteria Yang Digunakan

\begin{tabular}{|c|c|c|c|}
\hline No & $\begin{array}{c}\text { Kode } \\
\text { Kriteria }\end{array}$ & Keterangan & Bobot \\
\hline 1 & K1 & Penghasilan Tidak Tetap & 0.35 \\
\hline 2 & K2 & Tidak memiliki asset & 0.25 \\
\hline 3 & K3 & Memerlukan bantuan pangan untuk penduduk miskin & 0.15 \\
\hline 4 & K4 & Memiliki rumah diatas tanah milik sendiri & 0.15 \\
\hline 5 & K5 & Rumah yang dimiliki tidak layak huni & 0.1 \\
\hline
\end{tabular}

Tabel.2 Range Nilai Penghasilan

\begin{tabular}{|c|c|c|c|}
\hline No & Jumlah Penghasilan & Bilangan Fuzzy & Keterangan \\
\hline 1 & $3.000 .000-4.000 .000$ & Sangat Tinggi & 0 \\
\hline 2 & $2.000 .000-3.000 .000$ & Tinggi & 0.25 \\
\hline 3 & $2.000 .000-2.500 .000$ & Sedang & 0.5 \\
\hline 4 & $1.000 .000-1.500 .000$ & Rendah & 0.75 \\
\hline 5 & $500.000-1.000 .000$ & Sangat Rendah & 1 \\
\hline
\end{tabular}

Tabel.3 Range Nilai Aset

\begin{tabular}{|c|l|c|c|}
\hline No & \multicolumn{1}{|c|}{ Jumlah Nilai Aset } & Bilangan fuzzy & Keterangan \\
\hline 1 & $\begin{array}{l}\text { Memiliki hewan ternak kambing, sapi } \\
\text { dan memiliki 3 kendaraan bermotor }\end{array}$ & Sangat tinggi & 0 \\
\hline 2 & $\begin{array}{l}\text { Memiliki hewan ternak kambing, sapi } \\
\text { dan memiliki 2 kendaraan bermotor }\end{array}$ & Tinggi & 0.25 \\
\hline 3 & $\begin{array}{l}\text { Memiliki hewan ternak kambing dan } \\
\text { memiliki 1 kendaraan bermotor }\end{array}$ & $\begin{array}{l}\text { Sedang } \\
\text { tapi tidak memiliki hewan ternak }\end{array}$ & 0.75 \\
\hline 5 & $\begin{array}{l}\text { Tidak memiliki hewan ternak dan tidak } \\
\text { memilik kendaraan bermotor }\end{array}$ & Sangat Rendah & 1 \\
\hline
\end{tabular}

Tabel.4 Range Bantuan Pangan

\begin{tabular}{|c|l|c|c|}
\hline No & \multicolumn{1}{|c|}{ Kebutuhan Pangan } & Bilangan Fuzzy & Keterangan \\
\hline 1 & $\begin{array}{l}\text { Sangat membutuhkan bantuan pangan } \\
\text { raskin }\end{array}$ & Sangat Tinggi & 1 \\
\hline
\end{tabular}




\begin{tabular}{|c|l|c|c|}
\hline 2 & Membutuhkan bantuan pangan raskin & Sedang & 0.5 \\
\hline 3 & $\begin{array}{l}\text { Tidak membutuhkan bantuan pangan } \\
\text { raskin }\end{array}$ & Rendah & 0 \\
\hline
\end{tabular}

Tabel.5 Range kepemilikan Sertifikat

\begin{tabular}{|c|c|c|c|}
\hline No & Kepemilikan Sertifikat & Bilangan Fuzzy & Keterangan \\
\hline 1 & Memiliki sertifikat & Sangat Tinggi & 1 \\
\hline 2 & Sertifikat sedang dalam pengurusan & Sedang & 0.5 \\
\hline 3 & Tidak memiliki sertifikat & Sangat Rendah & 0 \\
\hline
\end{tabular}

Tabel.6 Range Kondisi Rumah

\begin{tabular}{|c|c|c|c|}
\hline No & Kondisi Rumah & Bilangan Fuzzy & Keterangan \\
\hline 1 & $\begin{array}{l}\text { Atap dari rumbia, lantai tanah, tidak } \\
\text { memiliki MCK dan dinding anyaman } \\
\text { bambu. }\end{array}$ & Sangat Tinggi & 1 \\
\hline 2 & $\begin{array}{l}\text { Atap dari rumbia, lantai semen,tidak } \\
\text { memiliki MCK dan dinding anyaman } \\
\text { bambu. }\end{array}$ & Tinggi & 0.75 \\
\hline 3 & $\begin{array}{l}\text { Atap dari seng, lantai semen, memiliki MCK } \\
\text { dan dinding dari papan. }\end{array}$ & Sedang & 0.5 \\
\hline 4 & $\begin{array}{l}\text { Atap dari seng, lantai semen, memiliki MCK } \\
\text { dan dinding dari batu bata. }\end{array}$ & Rendah & 0.25 \\
\hline 5 & $\begin{array}{l}\text { Atap dari genteng ,lantai kramik, dinding } \\
\text { dari batu bata dan memilik MCK. }\end{array}$ & Sangat Rendah & 0 \\
\hline
\end{tabular}

Berdasarkan dari Kriteria yang telah di dapatkan maka penilaian tersebut di normalilasi kriteria dengan fuzzy opsional sebagai berikut:

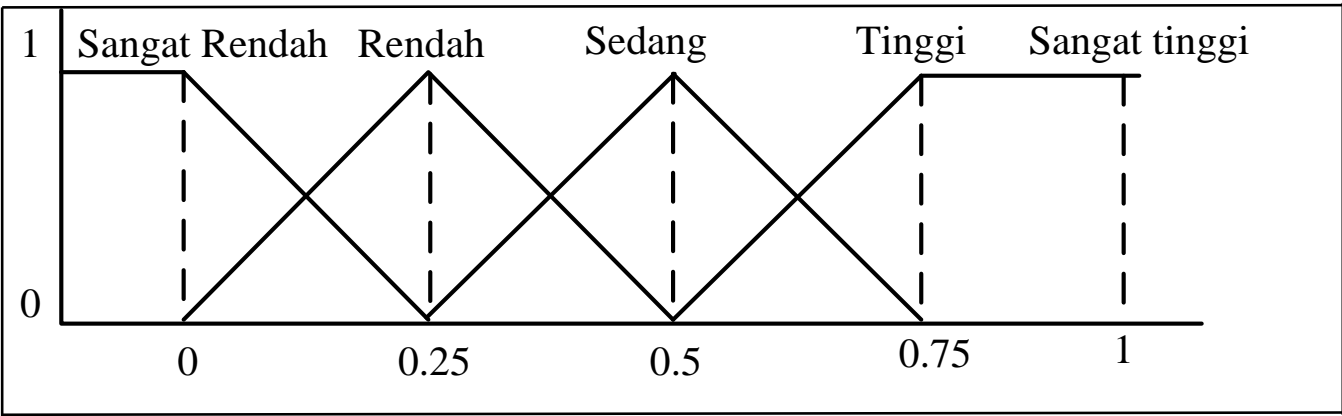

Gambar.1 Bilangan Fuzzy Penentuan Bobot

Selanjutnya nilai bilangan fuzzy di konversi ke dalam bilangan crisp seperti pada tabel berikut :

Tabel.7 Nilai crisp fuzzy 


\begin{tabular}{|c|c|c|}
\hline No & Bilangan Fuzzy & $\begin{array}{c}\text { Nilai Bilangan } \\
\text { Fuzzy }\end{array}$ \\
\hline 1 & Penilaian Sangat tinggi & 1 \\
\hline 2 & Penilaian Tinggi & 0.75 \\
\hline 3 & Penilaian sedang & 0.5 \\
\hline 4 & Penilaian rendah & 0.25 \\
\hline 5 & Penilaian Sangat Rendah & 0 \\
\hline
\end{tabular}

Tabel.8 Nilai normalilasi kriteria

\begin{tabular}{|c|c|c|c|}
\hline No & Bilangan fuzzy & $\begin{array}{l}\text { Nilai crisp } \\
\quad \text { fuzzy }\end{array}$ & Keterangan \\
\hline \multirow{5}{*}{ K1 (penghasilan) } & Penghasilan sangat tinggi & 0 & \multirow{5}{*}{$\begin{array}{l}\text { Semakin sedikit } \\
\text { penghasilan penilaian } \\
\text { semakin baik }\end{array}$} \\
\hline & Penghasilan tinggi & 0.25 & \\
\hline & Penghasilan sedang & 0.5 & \\
\hline & Penghasilan rendah & 0.75 & \\
\hline & Penghasilan sangat rendah & 1 & \\
\hline \multirow{4}{*}{$\mathrm{K} 2$ (aset) } & Nilai aset sangat rendah & 1 & \multirow{4}{*}{$\begin{array}{l}\text { Semakin sedikit aset yang } \\
\text { di miliki penilaian } \\
\text { semakin baik }\end{array}$} \\
\hline & Nilai aset rendah & 0.75 & \\
\hline & Nilai aset sedang & 0.5 & \\
\hline & Nilai aset tinggi & 0.25 & \\
\hline \multirow{5}{*}{$\begin{array}{l}\text { K3 (bantuan } \\
\text { pangan) }\end{array}$} & $\begin{array}{l}\text { Sangat tinggi kebutuhkan } \\
\text { bantuan pangan }\end{array}$ & 1 & \multirow{5}{*}{$\begin{array}{l}\text { Semakin tinggi kebutuhan } \\
\text { bantuan penilaian } \\
\text { semakin baik }\end{array}$} \\
\hline & $\begin{array}{l}\text { Tinggi kebutuhkan bantuan } \\
\text { untuk pangan }\end{array}$ & 0.75 & \\
\hline & $\begin{array}{l}\text { membutuhkan bantuan untuk } \\
\text { pangan }\end{array}$ & 0.5 & \\
\hline & $\begin{array}{l}\text { Cukup membutuhkan bantuan } \\
\text { pangan }\end{array}$ & 0.25 & \\
\hline & $\begin{array}{l}\text { Tidak membutuhkan bantuan } \\
\text { pangan }\end{array}$ & 0 & \\
\hline \multirow{2}{*}{$\begin{array}{l}\text { K4 (sertifikat } \\
\text { rumah) }\end{array}$} & Memiliki sertifikat rumah & 1 & \multirow{2}{*}{$\begin{array}{l}\text { Jika tidak memiliki } \\
\text { sertifikat rumah maka } \\
\text { penilaian } 0\end{array}$} \\
\hline & Tidak memiliki sertifikat & 0 & \\
\hline
\end{tabular}




\begin{tabular}{|l|l|c|l|} 
& rumah & & \\
\hline $\begin{array}{l}\text { K5 ( kelayakan } \\
\text { bangunan) }\end{array}$ & Bangunan sangat layak & 0.25 & $\begin{array}{l}\text { Semakin tidak layak } \\
\text { bangunan penilaian } \\
\text { semakin tinggi }\end{array}$ \\
\cline { 2 - 3 } & Bangunan layak & 0.5 & \\
\cline { 2 - 3 } & Bangunan cukup layak & 0.75 & \\
\cline { 2 - 3 } & Bangunan tidak layak & 1 & \\
\hline
\end{tabular}

Tabel.9 Penilaian calon penerima Kegiatan Bantuan RSRTLH

\begin{tabular}{|c|c|c|c|c|c|c|}
\hline No & Alternatif & $\begin{array}{c}\text { K1 } \\
\text { (penghasilan) }\end{array}$ & K2 (aset) & $\begin{array}{l}\text { K3 (bantuan } \\
\text { pangan) }\end{array}$ & $\begin{array}{c}\text { K4 } \\
\text { (sertifikat } \\
\text { rumah) }\end{array}$ & $\begin{array}{c}\text { K5 ( } \\
\text { kelayakan } \\
\text { bangunan) }\end{array}$ \\
\hline 1 & $\begin{array}{c}\text { BAMBANG } \\
\text { SALPIANTA.T }\end{array}$ & $\begin{array}{c}\text { Penghasilan } \\
\text { Tinggi }\end{array}$ & $\begin{array}{l}\text { Nilai aset } \\
\text { sedang }\end{array}$ & $\begin{array}{c}\text { cukup } \\
\text { membutuhkan } \\
\text { bantuan pangan }\end{array}$ & $\begin{array}{c}\text { Memiliki } \\
\text { Sertifikat } \\
\text { Rumah }\end{array}$ & $\begin{array}{c}\text { bangunan } \\
\text { cukup layak }\end{array}$ \\
\hline 2 & ABDUL HUSNI & $\begin{array}{c}\text { Penghasilan } \\
\text { Tinggi }\end{array}$ & $\begin{array}{l}\text { Nilai aset } \\
\text { sedang }\end{array}$ & $\begin{array}{c}\text { cukup } \\
\text { membutuhkan } \\
\text { bantuan pangan }\end{array}$ & $\begin{array}{c}\text { Memiliki } \\
\text { Sertifikat } \\
\text { Rumah }\end{array}$ & $\begin{array}{c}\text { bangunan } \\
\text { cukup layak }\end{array}$ \\
\hline 3 & $\begin{array}{c}\text { JHON EFENDY } \\
\text { SINAGA }\end{array}$ & $\begin{array}{l}\text { Penghasilan } \\
\text { sedang }\end{array}$ & $\begin{array}{l}\text { Nilai aset } \\
\text { sedang }\end{array}$ & $\begin{array}{c}\text { Tinggi } \\
\text { kebutuhkan } \\
\text { Bantuan untuk } \\
\text { pangan }\end{array}$ & $\begin{array}{c}\text { Memiliki } \\
\text { Sertifikat } \\
\text { Rumah }\end{array}$ & $\begin{array}{c}\text { bangunan } \\
\text { cukup layak }\end{array}$ \\
\hline 4 & SOPIAN & $\begin{array}{l}\text { Penghasilan } \\
\text { rendah }\end{array}$ & $\begin{array}{l}\text { Nilai Aset } \\
\text { Sangat } \\
\text { Rendah }\end{array}$ & $\begin{array}{c}\text { membutuhkan } \\
\text { bantuan untuk } \\
\text { pangan }\end{array}$ & $\begin{array}{c}\text { Memiliki } \\
\text { Sertifikat } \\
\text { Rumah }\end{array}$ & $\begin{array}{c}\text { bangunan } \\
\text { cukup layak }\end{array}$ \\
\hline 5 & $\begin{array}{c}\text { AFRIADI } \\
\text { DASOPANG }\end{array}$ & $\begin{array}{l}\text { Penghasilan } \\
\text { rendah }\end{array}$ & $\begin{array}{l}\text { Nilai Aset } \\
\text { Rendah }\end{array}$ & $\begin{array}{c}\text { cukup } \\
\text { membutuhkan } \\
\text { bantuan pangan }\end{array}$ & $\begin{array}{c}\text { Memiliki } \\
\text { Sertifikat } \\
\text { Rumah }\end{array}$ & $\begin{array}{l}\text { bangunan } \\
\text { tidak layak }\end{array}$ \\
\hline 6 & SUHENDRA & $\begin{array}{l}\text { Penghasilan } \\
\text { rendah }\end{array}$ & $\begin{array}{l}\text { Nilai aset } \\
\text { sedang }\end{array}$ & $\begin{array}{c}\text { membutuhkan } \\
\text { bantuan untuk } \\
\text { pangan }\end{array}$ & $\begin{array}{c}\text { Memiliki } \\
\text { Sertifikat } \\
\text { Rumah }\end{array}$ & $\begin{array}{l}\text { bangunan } \\
\text { tidak layak }\end{array}$ \\
\hline 7 & SUGITO & $\begin{array}{l}\text { Penghasilan } \\
\text { rendah }\end{array}$ & $\begin{array}{l}\text { Nilai Aset } \\
\text { Rendah }\end{array}$ & $\begin{array}{c}\text { Sangat tinggi } \\
\text { kebutuhkan } \\
\text { Bantuan Pangan }\end{array}$ & $\begin{array}{c}\text { Memiliki } \\
\text { Sertifikat } \\
\text { Rumah }\end{array}$ & $\begin{array}{l}\text { bangunan } \\
\text { tidak layak }\end{array}$ \\
\hline 8 & A.GHOZALI & $\begin{array}{l}\text { Penghasilan } \\
\text { rendah }\end{array}$ & $\begin{array}{l}\text { Nilai aset } \\
\text { sedang }\end{array}$ & $\begin{array}{c}\text { Tinggi } \\
\text { kebutuhkan } \\
\text { Bantuan untuk }\end{array}$ & $\begin{array}{c}\text { Memiliki } \\
\text { Sertifikat } \\
\text { Rumah }\end{array}$ & $\begin{array}{l}\text { bangunan } \\
\text { tidak layak }\end{array}$ \\
\hline
\end{tabular}




\begin{tabular}{|c|c|c|c|c|c|c|}
\hline & & & & pangan & & \\
\hline 9 & ASPAN & $\begin{array}{l}\text { Penghasilan } \\
\text { rendah }\end{array}$ & $\begin{array}{l}\text { Nilai Aset } \\
\text { Sangat } \\
\text { Rendah }\end{array}$ & $\begin{array}{l}\text { membutuhkan } \\
\text { bantuan untuk } \\
\text { pangan }\end{array}$ & $\begin{array}{l}\text { Memiliki } \\
\text { Sertifikat } \\
\text { Rumah }\end{array}$ & $\begin{array}{l}\text { bangunan } \\
\text { tidak layak }\end{array}$ \\
\hline 10 & ARIE SURYAWAN & $\begin{array}{l}\text { Penghasilan } \\
\text { sedang }\end{array}$ & $\begin{array}{l}\text { Nilai aset } \\
\text { sedang }\end{array}$ & $\begin{array}{c}\text { cukup } \\
\text { membutuhkan } \\
\text { bantuan pangan }\end{array}$ & $\begin{array}{c}\text { Memiliki } \\
\text { Sertifikat } \\
\text { Rumah }\end{array}$ & $\begin{array}{c}\text { bangunan } \\
\text { tidak layak }\end{array}$ \\
\hline
\end{tabular}

Kemudian setiap peserta yang telah di beri penilaian di konversi dalam bentuk normalisasi yang telah di rumuskan. Maka tabel penilaian penerima bantuan rehabilitasi sosial rumah tidak layak huni adalah sebagai berikut :

Tabel.10 Matriks Penilaian calon penerima bantuan RSRTLH

\begin{tabular}{|l|l|l|l|l|l|l|}
\hline No & \multicolumn{1}{|c|}{ Alternatif } & \multicolumn{1}{|c|}{ K1 } & \multicolumn{1}{|c|}{ K2 } & \multicolumn{1}{|c|}{ K3 } & \multicolumn{1}{|c|}{ K4 } & K5 \\
\hline 1 & $\begin{array}{l}\text { BAMBANG } \\
\text { SALPIANTA.T }\end{array}$ & 0.25 & 0.5 & 0.25 & 1 & 0.75 \\
\hline 2 & ABDUL HUSNI & 0.25 & 0.5 & 0.25 & 1 & 0.75 \\
\hline 3 & JHON EFENDY SINAGA & 0.5 & 0.5 & 0.75 & 1 & 0.75 \\
\hline 4 & SOPIAN & 0.75 & 1 & 0.5 & 1 & 0.75 \\
\hline 5 & AFRIADI DASOPANG & 0.75 & 0.75 & 0.25 & 1 & 1 \\
\hline 6 & SUHENDRA & 0.75 & 0.5 & 0.5 & 1 & 1 \\
\hline
\end{tabular}

\begin{tabular}{|l|l|l|l|l|l|l|}
\hline 7 & SUGITO & 0.75 & 0.75 & 1 & 1 & 1 \\
\hline 8 & A.GHOZALI & 0.75 & 0.5 & 0.75 & 1 & 1 \\
\hline 9 & ASPAN & 0.75 & 1 & 0.5 & 1 & 1 \\
\hline 10 & ARIE SURYAWAN & 0.5 & 0.5 & 0.25 & 1 & 1 \\
\hline
\end{tabular}

Kemudian di lakukan perhitungan dengan menggunakan metode WSM untuk mendapatkan prioritas penerima bantuan rehabilitasi sosial rumah tidak layak huni 
lakukan perkalian setiap alternatif dengan kriteria bobot yang telah di tentukan dengan rumus sebagai berikut

1. BAMBANG SALPIANTA.T

$$
\begin{aligned}
& =(0.25 * 0.35)+(0.5 * 0.25)+(0.25 * 0.15)+(1 * 0.15)+(0.75 * 0.1) \\
& =0.0875+0.125+0.0375+0.15+0.15+0.075 \\
& =0.475
\end{aligned}
$$

2. ABDUL HUSNI

$$
\begin{aligned}
& =(0.25 * 0.35)+(0.5 * 0.25)+(0.25 * 0.15)+(1 * 0.15)+(0.75 * 0.1) \\
& =0.0875+0.125+0.0375+0.15+0.075 \\
& =0.475
\end{aligned}
$$

\section{JHON EFENDY SINAGA}

$$
\begin{aligned}
& =(0.5 * 0.35)+(0.5 * 0.25)+(0.75 * 0.15)+(1 * 0.15)+(0.75 * 0.1) \\
& =0.175+0.125+0.1125+0.15+0.075 \\
& =0.6375
\end{aligned}
$$

4. SOPIAN

$$
\begin{aligned}
& =(0.75 * 0.35)+(1 * 0.25)+(0.5 * 0.15)+(1 * 0.15)+(0.75 * 0.1) \\
& =0.2625+0.25+0.075+0.15+0.075 \\
& =0.8125
\end{aligned}
$$

5. AFRIADI DASOPANG

$$
\begin{aligned}
& =(0.75 * 0.35)+(0.75 * 0.25)+(0.25 * 0.15)+(1 * 0.15)+(1 * 0.1) \\
& =0.2625+0.1875+0.0375+0.15+0.1 \\
& =0.7375
\end{aligned}
$$

6. SUHENDRA

$$
\begin{aligned}
& =(0.75 * 0.35)+(0.5 * 0.25)+(0.5 * 0.15)+(1 * 0.15)+(1 * 0.1) \\
& =0.2625+0.125+0.075+0.15+0.1 \\
& =0.7125
\end{aligned}
$$

7. SUGITO

$$
\begin{aligned}
& =(0.75 * 0.35)+(0.75 * 0.25)+(1 * 0.15)+(1 * 0.15)+(1 * 0.1) \\
& =0.2625+0.1875+0.15+0.15+0.1 \\
& =0.85
\end{aligned}
$$

8. A.GHOZALI

$$
\begin{aligned}
& =(0.75 * 0.35)+(1 * 0.25)+(0.75 * 0.15)+(1 * 0.15)+(1 * 0.1) \\
& =0.2625+0.125+0.1125+0.15+0.1 \\
& =0.75
\end{aligned}
$$


9. ASPAN

$$
\begin{aligned}
& =(0.75 * 0.35)+(1 * 0.25)+(0.5 * 0.15)+(1 * 0.15)+(1 * 0.1) \\
& =0.2625+0.25+0.075+0.15+0.1 \\
& =0.8375
\end{aligned}
$$

10. ARIE SURYAWAN

$$
\begin{aligned}
& =(0.5 * 0.35)+(0.5 * 0.25)+(0.25 * 0.15)+(1 * 0.15)+(1 * 0.1) \\
& =0.175+0.125+0.0375+0.15+0.1 \\
& =0.5875
\end{aligned}
$$

Jika hasil keputusan dari penilaian setiap alternatif lebih besar dari 0.5(50\%) maka alternatif tersebut layak mendapatkan bantuan RSRTLH. Berikut hasil penilaian setiap alternatif:

Tabel.11 Hasil Penilaian calon penerima bantuan RSRTLH

\begin{tabular}{|r|l|c|l|}
\hline \multicolumn{1}{|c|}{ No } & \multicolumn{1}{|c|}{ Alternatif } & Nilai akhir & \\
\hline 1 & Bambang salpianta.t & 0.475 & Tidak layak \\
\hline 2 & Abdul husni & 0.475 & Tidak layak \\
\hline 3 & Jhon efendy sinaga & 0.6375 & Tidak layak \\
\hline 4 & Sopian & 0.8125 & Layak \\
\hline 5 & Afriadi dasopang & 0.7375 & Tidak layak \\
\hline 6 & Suhendra & 0.7125 & Tidak layak \\
\hline 7 & Sugito & 0.85 & Layak \\
\hline 8 & A.ghozali & 0.75 & Tidak layak \\
\hline 9 & Aspan & 0.8375 & Layak \\
\hline 10 & Arie suryawan & 0.5875 & Tidak layak \\
\hline
\end{tabular}

\section{IMPLEMENTASI DAN PENGUJIAN}

\subsection{Kebutuhan Sistem}



berikut :

Dalam implementasi dan pengujian dibutuhkan suatu PC/ laptop yang spesifikasi minimum sebagai

1. Perangkat Lunak (Software)

a. Sistem operasi Windows 7

b. Visual Studio 2008

c. $\quad$ Microsoft Acces 2007

d. Crystal Report 8.5

2. Perangkat Keras (Hardware)

a. Laptop dengan spesifikasicorei3

b. Kapasitas hardisk 320GB

c. Memory VRAM $1024 \mathrm{MB}$

\subsection{Implementasi Sistem}

Implementasi daria plikasi Sistem Pendukung Keputusan Menentukan Penerima Bantuan Rehabilitasi Sosial Rumah Tidak Layak Huni dengan Metode WSM dapat terlihat dari hasil tampilan diantaranya menu data pokok dan analisa data.

\subsubsection{Tampilan Login}

Halaman login merupakan halaman yang disediakan sistem untuk digunakan sebagai hak akses bagi administrator yang akan membuka dan menggunakan aplikasi Sistem Pendukung Keputusan WSM . Adapun tampilan dari halaman login adalah sebagai berikut:

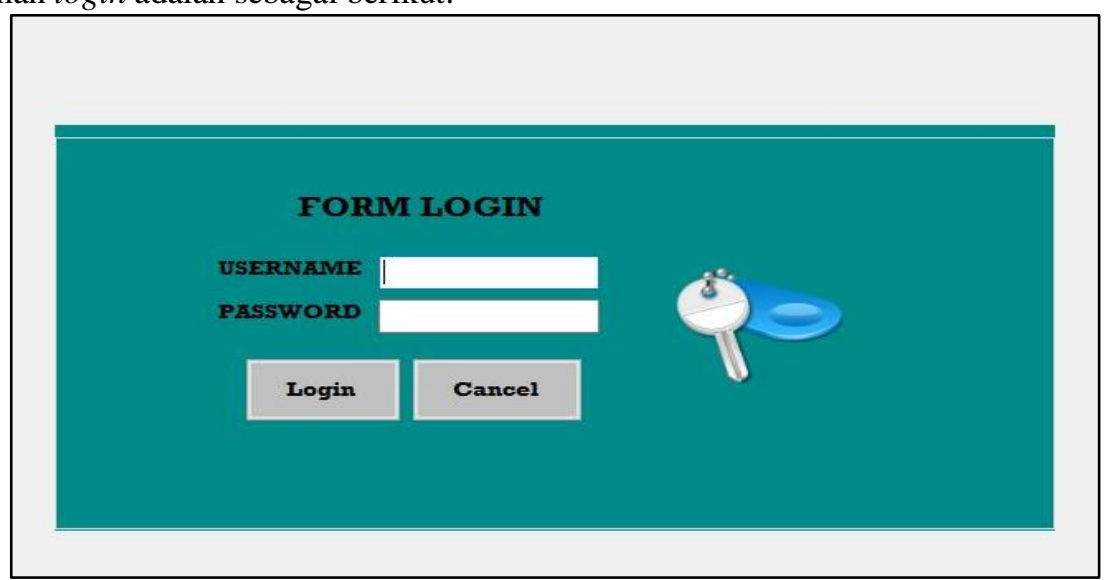

5.2.1 Gambar 4.1 Tampilan Halaman Login

\subsubsection{Tampilan Halaman Utama}

Halaman utama merupakan halaman pembuka aplikasi Sistem Pendukung Keputusan Menentukan Penerima Bantuan Rehabilitasi Sosial Rumah Tidak Layak Huni dengan Metode WSM setelah administrator melakukan login terlebih dahulu jika login berhasil maka akan tampil menu utama. Adapun tampilan dari halaman utama adalah sebagai berikut :

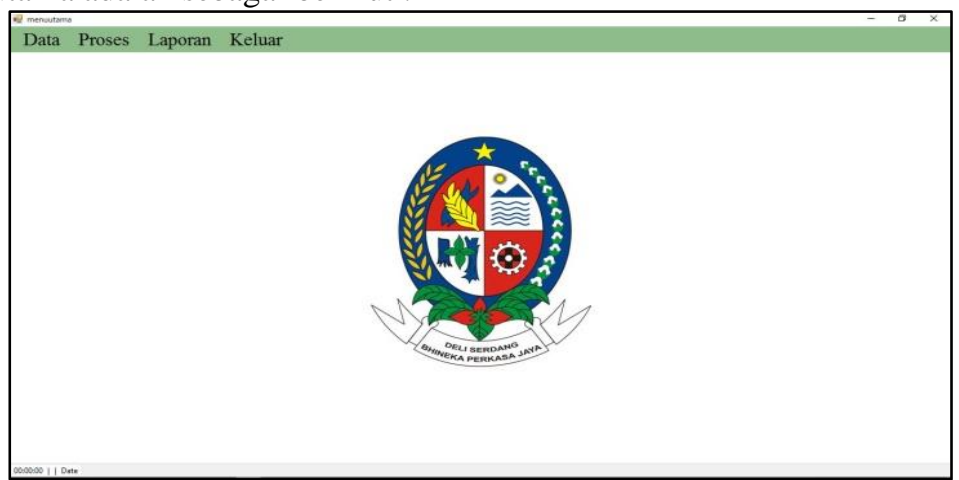

Gambar 4.2.2 Tampilan Halaman Utama

\subsubsection{Tampilan Halaman Menu Data}

Halaman menu data pokok merupakan halaman yang digunakan untuk penginputan data-data yang nantinya dapat digunakan sebagai parameter dalam perhitungan nilai kelayakan penerima bantuan, di dalam menu data pokok terdapat beberapa submenu, diantaranya adalah sebagai berikut : 
1. Halaman Submenu Data calon penerima

Halaman ini disediakan pada aplikasi Sistem Pendukung Keputusan Menentukan Penerima Bantuan rehabilitasi Sosial Rumah Tidak Layak Huni dengan Metode WSM digunakan untuk mengelola data penerima penyimpanan, mengubah, dan menghapus data. Berikut ini merupakan tampilan dari submenu data calon penerima.

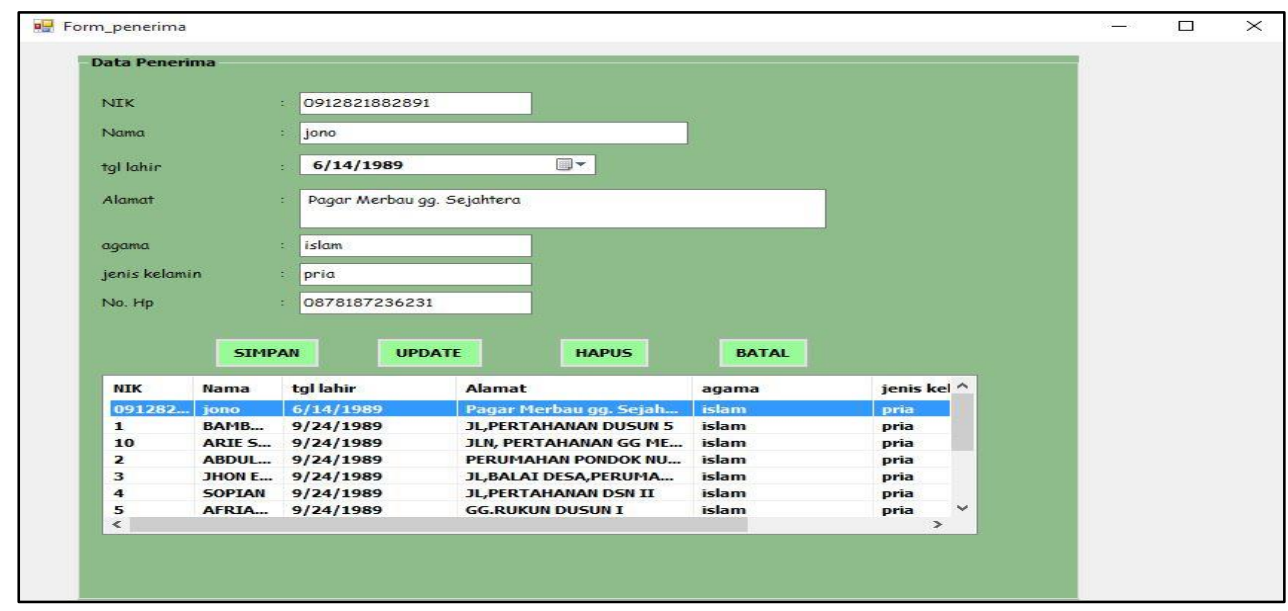

Gambar 4.2.3 Tampilan Halaman Data calon penerima

\section{Halaman Submenu Data kriteria}

Halaman ini disediakan pada aplikasi Sistem Pendukung Keputusan Menentukan Penerima Bantuan Rehabilitasi Sosial Rumah Tidak Layak Huni dengan Metode WSM digunakan untuk mengelola data kriteria berupa mengubah, data kriteria. Adapun tampilan dari submenu data kriteria adalah sebagai berikut :

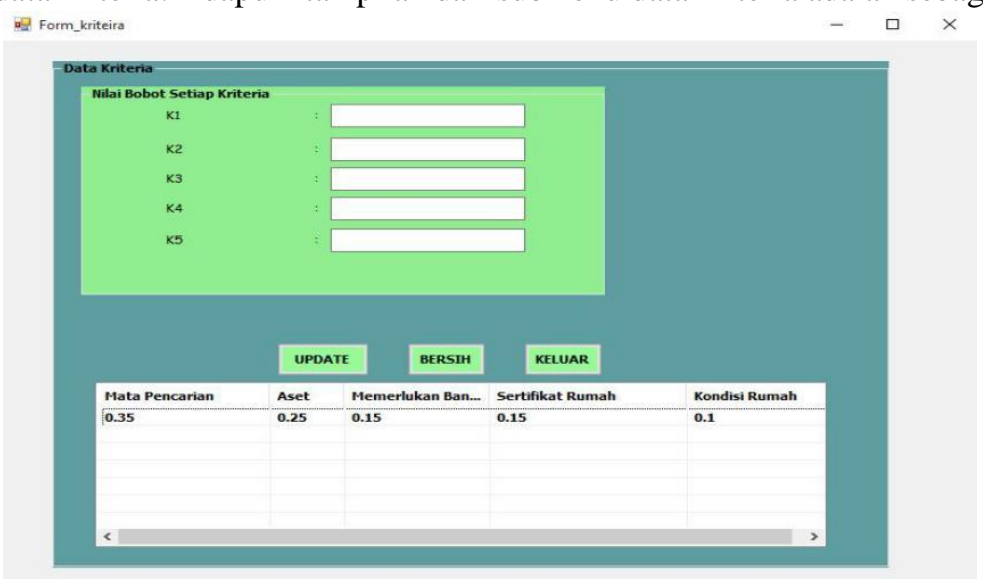

Gambar 4.2.4 Tampilan Halaman Data kriteria

\section{2.4 Tampilan Halaman Menu Proses}

Halaman menu proses merupakan halaman yang digunakan untuk pengolahan data yang nantinya akan dilakukanperhitungan nilai kelayakan penerima bantuan di dalam menu data proses terdapat beberapa submenu, diantaranya adalah sebagai berikut :

1. Halaman Submenu penilaian

Halaman ini disediakan pada aplikasi Sistem Pendukung Keputusan Menentukan Penerima Bantuan Rehabilitasi Sosial Rumah Tidak Layak Huni dengan Metode WSM digunakan untuk melakukan proses perhitungan nilai kelayakan calon penerima. Berikut ini merupakan tampilan dari submenu penilaian. 


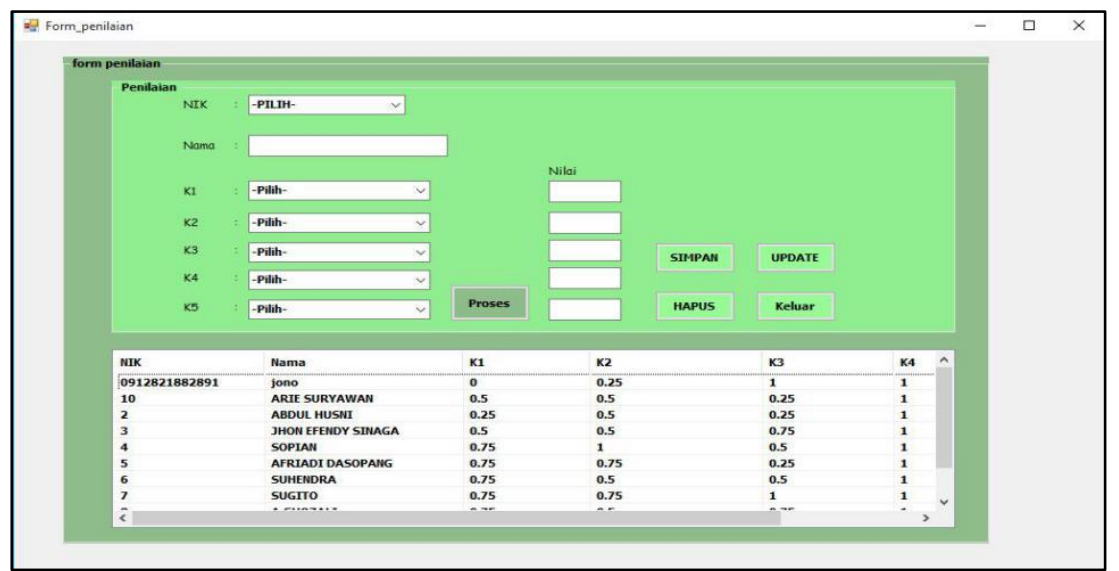

Gambar 4.2.5 Tampilan form penilaian

2. Halaman Submenu proses

Halaman ini disediakan pada aplikasi Sistem Pendukung Keputusan Menentukan Penerima Bantuan Rehabilitasi Sosial Rumah Tidak Layak Huni dengan Metode WSM digunakan untuk melakukan proses perhitungan nilai yang diperoleh dari hasil penilaian. Berikut ini merupakan tampilan dari submenu proses.

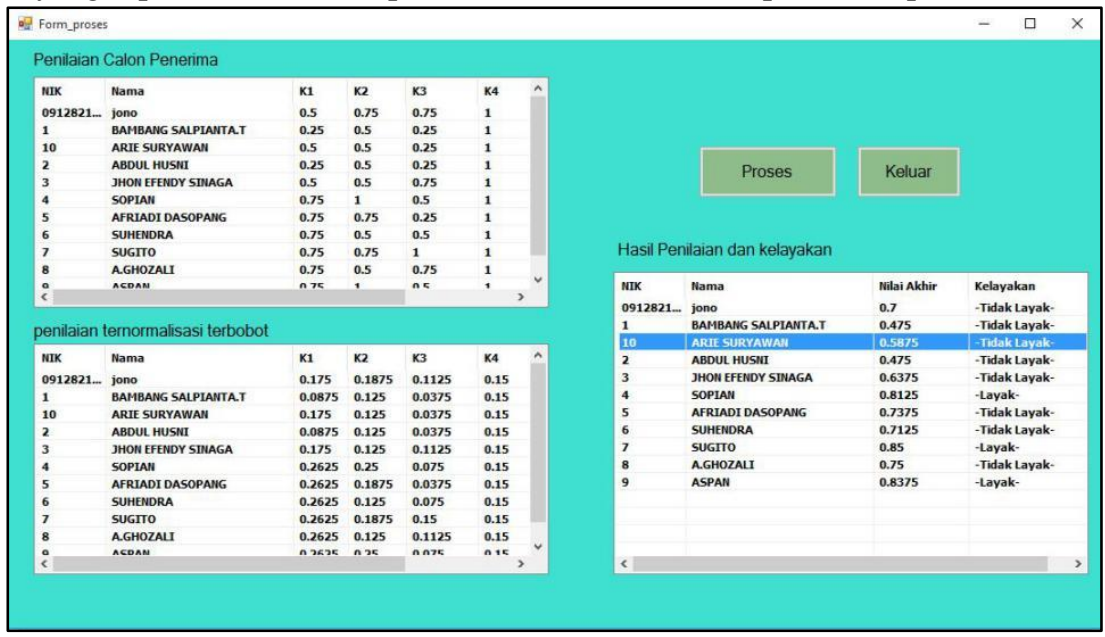

Gambar 4.2.6 Tampilan Halaman proses perhitungan

\subsection{Kelebihan Dan Kelemahan Sistem}

Aplikasi Sistem Pendukung Keputusan Menentukan Penerima Bantuan Rehabilitasi Sosial Rumah Tidak Layak huni dengan Metode WSM, terdapat beberapakelemahan dan kelebihan dalam perancangan dan pengaplikasiannya.

1. Kelebihan Sistem

a. Memberikan kemudahan dalam Sistem Pendukung Keputusan Menentukan Penerima Bantuan Rehabilitasi Sosial Rumah Tidak Layak Huni dengan Metode WSM dibanding cara konvensional.

b. Membantu pihak panitia perdaerah program Bantuan Rehabilitasi Sosial Rumah Tidak Layak Huni dalam mengetahui kelayakan calon penerima bantuan.

2. Kelemahan Sistem

a. Aplikasi sistem pendukung keputusan yang dirancang hanya digunakan untuk menghitung nilai berdasarkan kriteria mata pencarian tidak tetap, tidak memiliki asset, memerlukan bantuan pangan untuk penduduk miskin, memiliki rumah diatas tanah milik sendiri, Rumah yang dimiliki tidak layak hunisehingga tidak dapat melakukan perhitungan kelayakan jika terdapat kriteria yang baru, dikarenakan tidak memiliki fasilitas penambahan kriteria.

b. Sistem aplikasi ini hanya dapat menghasilkan laporan kelayakan secara keseluruhan tanpa melihat periode.

c. Sistem ini tidak memiliki fasilitas import data calon penerima sehingga admin harus menginputkan data secara manual. 


\subsection{Kesimpulan}

Setelah dilakukan implementasi program dan pengujian pada bab sebelumnya, maka dapat diambil beberapa kesimpulan sebagai berikut :

1. Adanya sistem pendukung keputusan yang dibangun dapat mempermudah pegawai kantor desa khususnya untuk kaur pembangunan desa yang akan melakukan proses penentuan penerima bantuan RSRTLH.

2. Adanya metode WSM, maka hasil penerima bantuan RSRTLH menjadi lebih akurat. Hasil calon penerima bantuan RSRTLH dapat di lihat dan sudah berbasis Dekstop.

\section{DAFTAR PUSTAKA}

[1] Hendrayudi., (2011) Dasar-Dasar Pemograman Microsoft Visual Basic 2008. $\quad$ Cetakan Ke1.Bandung : Satu Nusa

[2] Kusrini,M.Kom. (2007). Konsep Dan Aplikasi Sistem Pendukung Keputusan. Yogyakarta : Andi

[3] Masran,Sugunam,Surya Darma Nasution, Andsyah Putera Utama,. (2017) Penerapan Weight Sum Model (WSM) Dalam Penentuan Peserta Jaminan Kesehatan Masyarakat. Jurnal Riset Sistem Informasi Dan Teknik Informatika, Vol [2] No.1 Juli 2017. Hal 42

[4] Rosa A.S.,\& M.Shalahuddin. (2016). Rekayasa Perangkat Lunak. Bandung: Informatika Bandung.

[5] Suarna Nana., (2008) Pendoma Panduan Pratikum Microsoft Office Access 2007. Bandung : Yrama Widya

[6] Sumber:(http://ilmuKomputer.org/wpcontent/uploads/2009/anharkuflowchart.pdf)

[7] Sumber:(http://idebangunan.blogspot.co.id/2013/01/ciri-rumah-sehat-nyaman- dan-layak-huni.html)

[8] Sumber:(http://www.spengetahuan.com/2016/01/12-pengertian-rehabilitasi-menurut-para-ahliterlengkap.html).

[9] Sumber:(http://dellyani.blogspot.co.id/2013/05/definisi-dan-fungsi-rumah-tinggal.html)

[10] Sumber :( (http://rizkikhaharudinakbar.blogspot.co.id/2012/11/pengertian-rumah-fungsi-dansyarat.html).

[11] Sumber:(Wikipedia,2012).(http://cosprhmos.blogspot.co.id/2017/01/definisi-dan-fungsi-rumah.html)

[12] Elizabeth Triana.,\& Darmawan H Stephanie., (2015) Sistem Informasi Pemakaian Sparepart Mesin Packing pada PT. XYZ. Jurnal Program Studi Teknik Informatika, STMIK GI MDP, Palembang, 167. Jatisi, Vol. 1 No.2. Hal 167 